\title{
THE BIOLOGICALTEST OF FORMULATION OF SUBCULTURE Helicoverpa armigera Nuclear PolyhedrosisVirus(HaNPV) against Crocidolomia pavonana Fab. LARVAE POPULATIONTHAT EXPOSED TO CABBAGE
}

\section{(Brassica oleracea var. capitata L.)}

\author{
Anasthasia Vehuliza Surbakti, Mia Miranti, and Melanie \\ Department of Biology, Faculty of Mathematics and Natural Sciences, University of Padjadjaran \\ Jl. Raya Bandung Sumedang Km. 21 JatinangorSumedang \\ Correspondence author: anasthasia1204@gmail.com , miantariksa@gmail.com
}

\begin{abstract}
The biologicaltest of formulation of subculture Helicoverpa armigera Nuclear Polyhedrosis Virus(HaNPV) against Crocidolomia pavonana Fab.larvae population that exposed to cabbage (Brassica oleracea var. capitata L.) has been done. The subculture HaNPV was formulated in liquid preparations, powders, cornstarch and talc carrier materials, sprayed to $C$. pavonana larvae population that exposed at cabbage as a pilot project. The method of research used an experimental method, with randomized block design consists of single factor HaNPV and five level formulation there were (p) (liquid dosage forms (p1), powder (p2), and mixed with a carrier such as cornstarch (p3) and talc powder (p4) as well as the provision of water control without virus (p0)) with 8 replications. The density of virus $4 \times 10^{7}$ polyhedral $/ \mathrm{ml}$. The results was statistically analyzed with ANOVA $(p<0,05)$, showed that all formulation HaNPV subculture have equal ability to caused high mortality of $C$. pavonana larvae population.
\end{abstract}

Key words: Cabbage, Crocidolomia pavonana, Formulation,HaNPV, Mortality

\section{INTRODUCTION}

Cabbage (Brassica oleraceavar. capitata L.) of Cruciferaefamilia is one of a very popular vegetable plants. The part that is characteristic of this plant and used for consumption, namely the head of the leaves (crop). Part of the cabbage crop of these plants are often attacked by insect pests. Insect pests of cabbage the most destructive is Crocidolomia pavonana Fab. (Pracaya, 2000; Sastrosiswojo, 1981).

Physical quality of cabbage plants set prices, so farmers in Indonesia are spraying crops with synthetic insecticides which excessive amounts of cabbage that was not damaged by insect pests. The use of synthetic insecticides cause many negative effects. Prayogo \& Suharsono (2005), states that the impact of the use of synthetic insecticides namely environmental pollution and accumulation of insecticidal toxins in the food chain. One alternative for the control of insect pests using biological agents, that is virus. Insect virus mainly from Baculovirus group has great potential as a biological agent because this virus has the ability to kill specific insects and are harmless to vertebrates, especially mammals and humans (Indrayaniet al, 1993).

Nuclear Polyhedrosis Virus (NPV) is a pathogenic strain of Baculovirus group which is a natural pathogen for group class Insecta Lepidoptera (Maramorosch \& Sherman, 1985). HaNPV obtained through propagation or the production to do with method of in vivo. In vivo methods for HaNPV done conventionally using larvae of S. litura as a substitute host spread of the virus. HaNPV production of substitute host called HaNPV subculture. Pathogenicity of 
HaNPVsubculture appears to have remained stable (Indrayaniet al., 1993; Miranti, 2008). HaNPV subculture can be formulated in liquid and powder dosage forms with different material (carrier), especially to maintain the stability of the effectiveness of the virus during the storage period. Generally, carriers are often used to manufacture virus formulation is organic matter and minerals (Arsyad, 2009). Materials that can be used include talc powder and cornstarch because it is a protective, potentially as a carrier in the formulation HaNPV (Foster, 2012).

\section{MATERIALS AND METHODS}

\section{Infection the larvae of Spodopteralitura with preparation HaNPV subculture}

Spodoptera litura larvae used in this study to be made into a HaNPV subculture are the fourth instar larvae of 800 tails. Larvae of $S$. litura then maintained in the different groups in the zalp pots each containing 3 larvae. Then the larvae were fed cabbage that has been mixed with the virus using a density of $4 \times 10^{7}$ polyhedra / $\mathrm{ml}$. Cadaver larvae of S. litura collected and made into a HaNPV subculture. Virus production was calculated by using the hemocytometer to obtain the amount of virus polyhedra, in accordance with the treatment being tested.

\section{Formulation of HaNPV}

HaNPV of formulation in the form of powder preparation is done in a way that is HaNPV suspension dried at room temperature (about $25^{\circ} \mathrm{C}$ ) for 24 hours, until the virus powder is formed. HaNPV in a liquid preparation made by means HaNPV in stock be diluted with aquadest until a density that will be used, that is $4 \times 10^{7}$ polyhedra $/ \mathrm{ml}$. HaNPV formulated in the form of flour prepared by mixing virus liquid of known density of virus with talc and cornstarch flour each $100 \mathrm{gr}$ until blended. Then aerated for 24 hours (free sunlight). Once dry, the mashed mixture, and filtered with a sieve the flour until it forms a powder formulations virus (Arifin, 1993).

\section{Phase of the research}

Phase of the research that is to prepare them larvae of C. pavonana to be used for treatment.Larvae of C. pavonana the second instar larvae of 400 tails, separated into 50 containers with each containing 10 larvae.Once the cabbage plants 8-10 weeks after planting, crop cabbage will begin to form, and at the time it was done in accordance with the treatment HaNPV.Exposure conducted during the afternoon by spraying for liquid formulations and the virus spread to all parts of the cabbage crop for virus powder and formulation with a carrier cornstarch and flour talc. Then the larvae were exposed C. pavonana each for every 10 tails of cabbage plants. When larvae were exposed to the plant already, each polybag covered by gauze cage. Observations were made one day after application and subsequent HaNPV observed each day for 20 days trial.

\section{Measurement of parameters}

Parameters measured were larvae mortality in each treatment. Percentage mortality of larvae of $S$. litura calculated by the formula (Miranti, 2001): 


$$
\mathrm{M}=\frac{\sum n}{\sum N} \times 100 \%(2)
$$

$\mathrm{M}$ is the mortality (\%), $\mathrm{n}$ is the number of dead larvae (tail), and $\mathrm{N}$ is the number of larvae were tested (tail). Supporting parameters are number of individual larvae were able to survive to become pupa and imago during the period of 20 days of observation.

\section{RESULTS AND DISCUSSION}

Mortality result of observation C. pavonanaon cabbage plants that were exposed to the treatment of giving formulations HaNPV sub-culture in liquid preparations, powders, and the carrier in the cornstarch and talc can be seen in Figure 1.

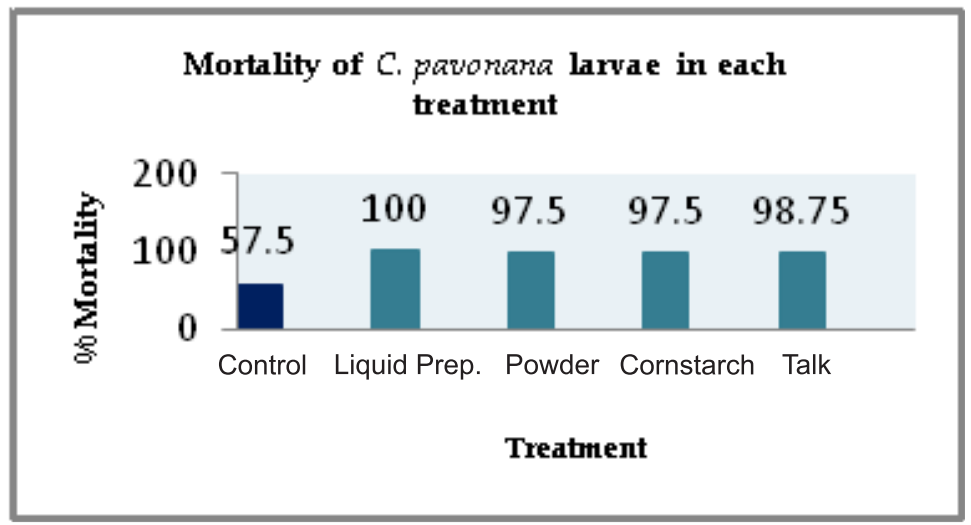

Figure 1. Bar chart of mortality C. pavonana larvae in each treatment

Figure 4.1 shows the percentage of insect mortality of C. pavonana the highest HaNPV caused by treatment formulations in the form of liquid preparation that is equal to $100 \%$. At all treatment formulations $\mathrm{HaNPV}$ produce a higher percentage of mortality than are control formulation without giving $\mathrm{HaNPV}$, but in the control treatment was also found the percentage of insect mortality in C. pavonana is equal to $57.5 \%$.

Data on the effect of sub-culture HaNPV formulations against larvae mortality of C. pavonana on cabbage plants were tested by ANOVA with a level of $5 \%$ as in Table 1.

Table 1. ANOVA analysis on mortality of larvae

\begin{tabular}{lccccc}
\hline $\begin{array}{c}\text { Source of } \\
\text { variation }\end{array}$ & DF & $\begin{array}{c}\text { Sum of } \\
\text { squares }\end{array}$ & $\begin{array}{c}\text { Mean } \\
\text { squares }\end{array}$ & F. ratio & $\begin{array}{c}\text { F- } \\
\text { probability }\end{array}$ \\
\hline Between & 7 & 57.5 & 8.214 & & \\
Within & 4 & 10760 & 2690 & 58.844 & 2.71 \\
Error & 28 & 1280 & 45.714 & & \\
Total & 39 & 12097.5 & & & \\
\hline
\end{tabular}

Statistical test results showed that all the formulations HaNPV treatment in the form of liquid preparations, powders and carrier in cornstarch and flour talc causes high mortality to the insect C. pavonana. Results are visible from the value F-ratio(58.844)> F-probability $(2,71)$. The results of ANOVA test followed by Duncan Multiple Range Test (Table 2) at the level of 
$5 \%$. The results of Duncan Multiple Range Test showed that the formulation HaNPV in liquid preparations, powders, and the carrier in cornstarch and flour talc provides the same value in causing mortality to $C$. pavonana larvae. The fourth type of formulation HaNPV was effective caused high mortality to larvae of $C$. pavonana.

Table 2. Mortality of $C$. pavonanalarvae in each HaNPV subculturetreatment

\begin{tabular}{cc}
\hline Treatment & Group \\
\hline p4 & $100 \mathrm{a}$ \\
p3 & $98,75 \mathrm{a}$ \\
p2 & $97,5 \mathrm{a}$ \\
p1 & $97,5 \mathrm{a}$ \\
p0 & $57,5 \mathrm{~b}$ \\
\hline
\end{tabular}

${ }^{\star}$ Each the average that have the same letter was stated are not significantly different at the level of $5 \%$.

Research data show that HaNPV formulations in liquid dosage forms cause mortality C. pavonana highest, amounting to $100 \%$. This is because at the time of spraying liquid preparation to plant cabbage, a liquid preparation is hard stick on cabbage leaves have a waxy coating and the liquid will be directly attached and dried on cabbage. Larvae of C. pavonana has properties liked the part of the growing point or cabbage crop that contains many amino acids and minerals (Sastrosiswojo \& Setiawati, 1993). At the time of larval C. pavonanathe second instars were exposed at the surface of cabbage leaves, the larvae will toward the cabbage crop. However, because the cabbage crop section contained a liquid preparation that attaches and dries the virus polyhedra will be directly ingested by the larvae. The more polyhedra are ingested, the more virions that infect cells and larval tissues until eventually cause death.

\section{ACKNOWLEDGMENT}

Authors would like to thank the parents, faculty mentors, and friends of the Department of Biology, Padjadjaran University who participated actively during the study.

\section{REFERENCES}

Arsyad, M. 2009. Studi Isolasi Bakteri Rhizobium yang Diinokulasikan Ke Dalam Dolomit Sebagai Pembawa (Carrier) Serta Pemanfaatannya Sebagai Pupuk Mikroba. Thesis. University of North Sumatra. Medan.

Foster, N. 2012. What Is Corn Starch.http://www.wisegeek.com/what-is-cornstarch.htm. Retrieved October 16 at 18:09 pm.

Indrayani, I.G.A.A., D. Winarno, and Soebandrijo. 1993. Efektivitas Npv Dengan Berbagai Bahan Pembawa Terhadap Spodoptera litura F. dan Helicoverpa armigera Hubner Pada Kapas. Juli 1995-Juni 1996. Installation Asembagus Research, Situbondo, East Java.

Maramorosch, K. and K.E. Sherman. 1985. Viral Insecticides for Biological Control. London :Academic Press Inc. 
Miranti, M. 2001. Pengaruh Dosis Helicoverpa armigera Nuclear Polyhidrosis Virus (HaNPV) dan Stadia Larva Terhadap Sifat Fisiologis dan Mortalitas Larva Helicoverpa armigera (Hubner). Thesis. Faculty of Agriculture UNPAD. Not Published.

Miranti, M. 2008. Produksi Helicoperva armigera Nuclear Polyhedrosis Virus (HaNPV) Secara In Vivo pada Inang Pengganti. Dissertation. Faculty of Agriculture UNPAD. Not Published.

Pracaya. 2000. Kol Alias Kubis. Penebar Swadaya. Jakarta.

Prayogo.Y danSuharsono. 2005. Optimalisasi pengendalian hama pengisap polong kedelai (Riptortus linearis) dengan cendawa nentomo patogen Verticillium lecanii. Crops Research Institute for Legumes and Tuber Crops. Malang.

Sastrosiswojo, S.H. 1981. Pengendalian Hama-hama Kubis SecaraTerpadu. Department of Agriculture, Agency for Agricultural Research and Development Sub Research Institute for Food Crops. Berastagi.

Sastrosiswojo, S.H., W. Setiawati. 1993. Biology and Control of Crocidolomia binoatalis in Indonesia. Lembang Holticultural Research Institute (LEHRI). 